\title{
O provérbio nas estórias de Guimarães Rosa e Mia Couto'
}

\author{
The proverbs in the stories of Guimarães Rosa and Mia Couto
}

\author{
EDUARDO DE ARAÚJO TEIXEIRA \\ Universidade Federal do Rio de Janeiro - Rio de Janeiro - Rio de Janeiro - Brasil
}

Resumo: Este estudo analisa o emprego dos provérbios nas narrativas do brasileiro João Guimarães Rosa e do moçambicano Mia Couto. Além de indicarmos paralelas e tangentes deste uso nos dois autores, mostramos como a apropriação dos ditos populares (e sua posterior reelaboração), revelam vínculos profundos que ambos escritores estabelecem com seus universos socioculturais. Para além do resgate e respeito à tradição oral, comprovamos que o uso do provérbio nestes autores revela compromisso com a expressividade, uma postura crítica diante da linguagem, e questionamento ideológico das sociedades tematizadas em suas literaturas.

Palavras-chave: Provérbios; Literatura; Mia Couto; Guimarães Rosa; Comparada

\begin{abstract}
This study analyzes the use of proverbs in Brazilian narratives João Guimarães Rosa and the Mozambican Mia Couto. Besides we indicate parallel and tangent of this use in two authors, we show how the appropriation of popular sayings (and subsequent reworking), reveal deep ties that both writers establish with their social and cultural universes. In addition to the rescue and respect the oral tradition, we proved that the use of saying these authors reveals commitment to expression, a critical attitude to language, and ideological questioning of themed societies in their literature.
\end{abstract}

Keywords: Proverbs; Literature; Mia Couto; Guimarães Rosa; Comparative Literature

Kambua kikamba Nzambi; muntu limonho uisesula

[Palavra proferida por Deus,

compete ao homem completá-la]

Quem estraga a sua palavra, estraga a si mesmo

Adágio africano

"Verba volant, scripta manent", ensina o célebre provérbio latino. Aceitar, entretanto, que $o$ dito se dispersa, enquanto o escrito perdura, implica reconhecer a contradição existente no emprego do provérbio, expressão da oralidade, para reafirmar a força da palavra escrita. Sendo contraditório o conceito ante a forma, o ensinamento se perde, pois sua verdade se dissolve, convertida em palavra fácil, falácia.

Embora tal provébio soe inicialmente como um axioma, sua própria autonomia como sentença torna possível o reconhecimento de sua lógica contraditória.

\footnotetext{
1 Este trabalho contou com o Programa de Apoio ao Pós-doutorado pelo Convênio CAPES/FAPERJ - 2011 (Edição E_10), pois está inserido na pesquisa desenvolvida no PACC - Programa Avançado de Cultura Contemporânea - Faculdade de Letras da UFRJ, sob supervisão da Prof $^{a}$ Dr $^{\mathrm{a}}$. Heloisa Buarque de Hollanda.
}

Se nele há contradição, é por que seu espaço de difusão é a fala, expressão de certa sabedoria popular a preservar um ensinamento que, cristalizado, avança de geração em geração, pelo suporte da memória, dispensando o escrito. Reiterando essa ideia, o provérbio - apesar de traduzir o senso-comum - subverte o efêmero da palavra falada, não se dispersa, salta de lábio a ouvido, é memorizado, por vezes se altera num outro registro, outro idioma, apresentando, para além de seu tempo e lugar, novas variantes, seja na forma ou no conceito que encerra.

O provérbio pertence a uma categoria fraseológica ampla e complexa, a começar pelo grande número de sinônimos que congrega: adágio, aforismo, anexim, axioma, brocardo, ditado, ditanga, dito popular, estribilho, máxima, princípio, proposição, refrão, rifão, sentença, parêmia etc. Há distinções entre esses termos, mas aqui o que nos 
interessa é sua acepção como "expressão popular, breve e conceituosa." Estruturalmente, os provérbios prescindem frequentemente de verbos, organizam-se numa forma elíptica, através da qual o verbo pode ser mentado (suposto), podendo se apresentar em prosa ou em verso numa sentença curta, incisiva, direta, sumária. É comum compor-se de duas unidades em paralelismo, admite antíteses, e pode figurar causa e efeito. Utiliza uma conceituação abstrata, metafórica, enigmática ou simbólica; que por sua propriedade de encaixe (às vezes, vacuidade), adere a inúmeros contextos. $70 \%$ podem admitir o verbo ser ou correlatos, excepcionalmente o haver, e mais raramente, outros.

Neste trabalho trataremos de analisar o emprego dos provérbios nas narrativas de dois autores, o brasileiro João Guimarães Rosa e o moçambicano Mia Couto. O objetivo é, não apenas reconhecer as paralelas e tangentes deste uso, mas mostrar como a apropriação dos ditos populares, e sua posterior reelaboração, são reveladoras dos vínculos profundos que ambos os escritores estabelecem com seus universos socioculturais; e mais agudamente, do compromisso com a expressividade, postura crítica diante da linguagem e questionamento ideológico.

\section{Sobre o provérbio}

O provérbio origina-se na sabedoria popular; é parte do folclore dos povos e está calcado em duas vertentes: uma de "aconselhamento", e a outra de "crença." Seu anonimato e sua inclinação didático-ilustrativa o aproximam de uma sabedoria que facilmente se confunde com uma verdade sem amarras, universal. Isto se deve não só ao fato de refletir uma experiência humana (individual ou coletiva), mas por permitir, pelas imagens rústicas e prosódicas facilmente assimiláveis, que seja tomado por um paradigma ético; uma estratégia para lidar com situações-problemas. Seriam, conforme a paremióloga Ana Maria Vellasco: "uma manifestação do passado cristalizado no presente" (Cf. VELLASCO, 2002:7).

$\mathrm{O}$ emissor; recorrendo à memória, insere no seu discurso o provérbio, que pode ou não ser conhecido do receptor, mas que de todo modo, fará com que este imediatamente o relacione com a questão presente, associando o provérbio ao seu contexto. Através da comparação entre o seu ponto de impasse e a solução contida no provérbio, desenha uma solução possível ou uma postura diante da questão: A moça tem dúvidas se deve ou não insistir num noivado interminável? - Água mole e pedra dura, tanto bate até que fura.

A primeira função do provérbio parece ser orientar; ou seja, apontar um caminho. Frequentemente ele é utilizado para indicar a direção mais segura, porque percorrida pela experiência. Porém, mais que direcionar, ele redireciona decisões e vontades para um determinado rumo; numa linha imprecisa entre conduzir e induzir; revelando-se um eficiente mecanismo de persuasão. Não por acaso este é o motivo pelo qual ele é frequentemente utilizado e imitado pela linguagem publicitária, predominantemente conativa.

Não se deve entender que a persuasão reporte somente a uma postura ativa; pois ela compreende também o seu revés, que é a aceitação, a passividade diante daquilo que se mostra superior à ação do indivíduo. Provérbio e sagrado se encontram unidos nas mais diversas culturas, seja no mundo tradicional africano, seja no texto bíblico; expressando sempre uma instrução de prudência ou crença em forças superiores divinas. Isto fica claro nos provérbios que revelam a existência de forças imateriais que regem o destino humano, e que zelam por ele. Isto é dado de forma implícita em ditos que tratam da atuação benéfica de forças que equacionam perda e ganho, carência e prosperidade, sorte e azar. O terceiro filho também perdeu o emprego? Depois da tempestade vem a bonança.

Esta longa explanação é necessária para que se entenda que a passagem do provérbio para o texto escrito estabelece uma outra relação com o receptor-leitor - antes receptor-ouvinte. Ela implica a perda do contato com o interlocutor-imediato; e um esvaziamento da força do próprio provérbio, seja como estratégia persuasiva, seja como ensinamento. Se houve adesão de Guimarães Rosa e Mia Couto a esta forma popular, que veio "no bojo" de toda uma herança linguística, alicerçada também numa particularíssima visão de mundo; ela não prescindiu de uma reestruturação na forma e no sentido, para no final, colaborar com o propósito de ambos os autores: exceder sua significação convencional, visando o efeito mais expressivo na linguagem literária. Por essa razão escreve Mia Couto, em Mar me quer: "- A senhora conhece o ditado, não conhece? Mais vale uma mão no pássaro." (COUTO, 2004:28). Por essa razão escreve Guimarães Rosa, em Sagarana: “- Melhor um pássaro voando do que dois na mão!... Eis a versão do provérbio, para uso dos fortes, dos capazes de ideal..." (ROSA, 1971:181).

\section{O provérbio em João Guimarães Rosa}

O provérbio não apresenta uma faceta única no conjunto da obra rosiana; pois vai se alterando a cada novo projeto estético do autor. A adesão ao provérbio reflete o processo gradual de apropriação e aprofundamento da linguagem popular, subordinados aos dois parâmetros que Rosa considerava ideais para realização plena da escritura: essência e acentuação.

Num primeiro momento, o de Sagarana, os provérbios são basicamente transpostos para a fala dos personagens e se apresentam, na maior parte dos casos, entre aspas. Nem por isso produzem estranhamento, ao contrário, são de um realismo próximo ao documental, pois as expressões são 
apresentadas em estado bruto, inseridas num contexto de atuação dinâmica dos personagens:

- Terra com sede, criação com fome", seu Oscar... (ROSA, 1971:93)

- Vamos, gente, pessoal, quem vai na frente bebe a água limpa!" Voz pomposa, Raymundão, o branco de cabelo negro: - (...) (ROSA, 1971:11)

- Olha pra mim, Francolim: "joá com flor formosa não garante terra boa!... (ROSA, 1971:13)

- Mais coragem, Manico, sem gemer... Suspiro de vaca não arranca estaca!... (...)! Quem tem inimigo não dorme!... (ROSA, 1971:18)

- Há-há, Manico velho! Escuta: “para bezerro mal desmamado, cauda de vaca é maminha..." (...) Galinha tem muita cor, mas todo ovo é branco. (ROSA, 1971:34)

- Bem, se o senhor dá a conta por liquidada, eu lhe pego da palavra, porque "sal da seca é que engorda o gado!... (ROSA, 1971:90)

Mas, para além de uma mera inserção competente no discurso, Rosa já se inclina para uma assimilação do processo estrutural. Por exemplo, em "A hora e vez de Augusto Matraga", alonga vários provérbios: “- Sorte nunca é de um só, é de dois, é de todos... Sorte nasce cada manhã, e já está velha ao meio-dia..."(ROSA, 1971:330); em "São Marcos", emprega uma expressão que possui características proverbiais, mas que termina por se revelar falsa, pois seu sentido é literal: “(...) Pé por pé, pé por si (...) (ROSA, 1971:251)"; extremamente pertinente ao jogo sonoro (onomatopéico) dos passos de um homem cego no meio de uma floresta.

Contudo, o melhor exemplo da relação intrínseca provérbio/narrativa, se encontra em "A hora e vez de Augusto Matraga", o conto narra uma trajetória catártica que ilustra perfeitamente o dito popular "Tudo tem sua hora, cada qual tem seu dia". Este dito, por sua vez, é um eco recuperado da lição de fé e paciência irrestrita à Divina Providência, atribuída a Mateus $(5,7 ; 10,29)$, em livro homônimo que integra a Bíblia católica.

Augusto Matraga é um fazendeiro cruel que humilha esposa e empregados, odiado por toda comunidade. Um coronel da região manda matá-lo, mas muito ferido ele escapa caindo num precipício onde será resgatado por um casal de velhos. Recebendo um padre prestes a morrer, jura voltar-se para Deus pois almeja um lugar no céu. Sua redenção faz-se através do trabalho exaustivo e da abdicar aos luxos e prazeres mundanos. Por fim, sua "hora e vez" chega ao morrer num duelo sangrento contra cangaceiros, a fim de defender um velho e seus netos. Não só porque o provérbio serve de ponto de partida para redenção do protagonista (no conselho dado "em forma de ditado" pelo padre), mas pelas variações da mesma expressão continuamente reiteradas ao longo da trama na fala dos mais diversos personagens, que podemos observar a força dos valores cristãos na obra rosiana. Este provérbio se converte, portanto, na síntese do relato de Matraga, o que torna possível a nós considerarmos, até pela constatação de sua presença no título do conto, seu mote originário (“A hora e vez de...”):

(...) Cada qual tem o seu dia... (...) (ROSA, 1971:197)

Assim, quase qualquer um capiau outro, (...) teria percebido a chegada do azar, da unhaca, (...) para esperar o cumprimento do ditado: "Cada um tem seu seis meses..." (ROSA, 1971:345)

(...). e tudo foi bem assim, porque tinha de ser, já que assim foi. (ROSA, 1971:345).

Num segundo momento, que compreende todo o Corpo de baile e o Grande sertão: veredas; os provérbios se tornam mais raros, talvez porque o interesse do autor não seja mais incorporar ao texto os ditos folclóricos, mas criar, graças à assimilação da técnica de montagem proverbial, suas próprias sentenças curtas e solenes, que terminam por constituir posteriormente, uma de suas marcas estilísticas. O discurso narrativo passa a ser extremamente simbólico e metafórico, com períodos inteiros soando como máximas atemporais, compondo, por sua vez, enigmas textuais que simulam escrituras místico-religiosas.

- Mais antes um que mal procede, mas que ensina pelo direito a reza dos usos. (ROSA, 1986:44)

Viver é muito perigoso... Querer o bem com demais força, de incerto jeito, pode já estar sendo se querendo o mal, por principiar. Esses homens! Todos puxavam o mundo para si, para o concertar consertado. Mas cada um só vê e entende as coisas dum seu modo. (...) (ROSA, 1984:9)

(...) Acontecia o seguinte, o que viesse vinha; tudo não é sina? (...) Caminhar de noite, no breu, se jura sabença: o que preza o chão - o pé adivinha. (...) (ROSA, 1984:176)

No terceiro e último momento, que compreende Primeiras estórias e Tutaméia, os provérbios mais convencionais serão fartamente utilizados, principalmente em Terceiras estórias. Rosa passa a efetuar uma distorção radical na forma do provérbio, recriando-os. Isto atingirá um grau maior nas narrativas de humor (cômicas/ou patéticas), num intenso, criativo e lúdico procedimento de recriação que permeia o nonsense.

Dentre tantos provérbios contidos nas duas obras, podemos destacar as seguintes: "O pior cego é o que quer 
ver"; "Só sendo cego quem não deve ver", "Mas ninguém espera a esperança", "No devagar de ir longe", "O roto só pode mesmo rir é do esfarrapado", "Deus é quem sabe o por não vir", "O pão é o que faz o cada dia", "Não me digar: do lobo, a pele, e olhe lá!", "De manhã, todos os gatos são nítidos nas pelagens", "Tanto vai a nada a flor, que um dia se despetala"

É, portanto, como se o autor, no seu propósito de fugir ao lugar-comum (e outras formas estereotipadas), se empenhasse na desconstrução/reconstrução para tornar novamente "inteligíveis" - para não dizer visíveis - tais expressões. Ao propiciar o reconhecimento do padrão a partir da forma desrespeitada, Rosa leva o leitor ao riso. Ridendo Castigat Mores - ensina a máxima. Ao subverter a forma para revelar o senso-comum que está no cerne de cada provérbio; descortina o olhar crítico do leitor para com as convenções de seu tempo.

Antes de encerrar este exame, é importante observar que as obras publicadas postumamente, Estas estórias e Ave, palavra, não chegam a constituir um modo outro, pois apresentam pequenas variações que reiteram, quase em sua totalidade, os procedimentos já analisados. Convém, entretanto, destacar o uso dos ditos populares em "A estória do homem do pinguelo", pelo acúmulo de provérbios que a caracteriza, e também pela referência explícita, por meio de um procedimento metalinguístico através do qual dois narradores (um popular, outro erudito) contam/analisam a narrativa (de mistério) que eles próprios engendram:

- Credo que não. É mal ver que, às ora vezes, a gente mal vive, por tudo. Mas, também, cá não me queixo, nem da roda nem do eixo. Jamais, nunca, eu invejei ninguém: porque inveja é erro de galho, jogar jogo sem baralho. (...): não haverá dois cipós que não acabem se emendando. (...), do que se vive e que se vê, a gente toma a proveitosa lição não é do corrido, mas do salteado. (...)

Súbito acúmulo de adágios - recurso comum ao homem do campo, quando tenta passar-se da rasa realidade, para principiar em fórmulas, suas abstrações. (ROSA, 1984a:101).

A pesquisadora literária Edna Tarabori Calobrezi, em seu estudo sobre Estas estórias, escreve acerca do uso dos provérbios nesta narrativa:

Todavia é interessante notar que o uso do provérbio, no conto, propõe uma tensão entre o velho e o novo de um lado, temos o seu emprego abundante pelas personagens, prática representativa da tradição, e, de outro, o rearranjo de sua estrutura ("E o que veio se meter em feixe de estreitas talas" - EE, p. 123), parecendo refletir a tentativa de rompimento com o esquema de viver. Logo, no provérbio remotivado ou no clichê reconstruído confrontam-se o passado, o já estabelecido, a permanência na mesmice e, simultaneamente, o futuro, o desconhecido, a busca de mudança. (CALOBREZI, 2001:155-156.)

No acervo de João Guimarães Rosa, do Instituto de Estudos Brasileiros da Universidade de São Paulo, encontram-se diversos recortes de jornais com listas de provérbios, além de várias listagens feitas à mão pelo autor em papéis avulsos e em suas famosas cadernetas, demonstrando o rigor e interesse profundo do autor pela paremia. As obras de publicação póstumas confirmam, portanto, a continuidade das experimentações e o interesse de Rosa pelos provérbios que, como se observou, jamais cessaram.

Por fim, é importante entender que este quadro geral não exclui a ocorrência de mudanças mais sutis do emprego da forma proverbial no autor mineiro, motivada pelo próprio andamento geral da obra ou de seu enredo, que, por necessitar de um estudo mais amplo e aprofundado, não pode aqui ser abarcado.

\section{O provérbio em Mia Couto}

Assim como na obra rosiana, o provérbio está presente na maior parte dos trabalhos de Mia Couto, com variações notáveis quanto forma e emprego. Observa-se, entretanto, que as variações não se fazem progressivamente; pois os ditados se alteram dentro de um mesmo livro, quando não, num único texto. Isto revela uma postura diferenciada de Mia Couto, expressa pelo tratamento dado aos provérbios ocidentais, bem distinto àquele aplicado aos de tradição africana.

Excetuando Vozes anoitecidas (sua estreia na prosa), todos os demais livros do autor fornecem um número variado de provérbios, tanto ocidentais quanto africanos. Os primeiros, provenientes da herança linguística portuguesa, aparecem em sua obra (ao lado das frasesfeitas, lugares-comuns e outras expressões cristalizadas e estereotipadas) já pela forma desconstruída/reelaborada; mais especificamente, com a preservação da estrutura rítmica, mas com transgressões sintáticas de seus termos integrantes (em nível morfológico).

Estórias abensonhadas fornece fartos exemplos do processo de reinvenção efetuado quase na totalidade da criação coutiana, por sua vez, mais acentuada nas estórias de inclinação cômica e/ou patética: "Estava como nunca esteve S. Tomé: via para não crer", "E sem água ida nem vinda", "Entre marido e mulher o tempo metera a colher.", "Para entendedor como ela meia palavra já é de mais", "Tudo está longe das vistas, perto do coração", "Na parede de um gabineto todas as espingardas são Pardas", "Olho por olho, dente prudente, "nem tanto há mar, nem 
tanto há terra; quem é vivo sempre desaparece", "Escrevo como Deus: certo mas sem pauta"; e uma infinidade de outros.

Similar ao procedimento de reinvenção lúdica dos estereótipos linguísticos efetuado por Rosa a partir de Primeiras Estórias, Mia Couto provoca, ao "desrespeitar" a forma matriz, não só o estranhamento, mas o humor; que surge do reconhecimento da forma parodiada pelo leitor.

Edna Nascimento escreve em sua tese sobre metalinguagem natural

Um aspecto especial da desconstrucão se apresenta quando segmentos fraseológicos (chavões), portanto pertencentes ao repertório de nossa língua, produz um ruído no discurso, reação do leitor ao clichê que lhe serviu de matriz. Percebendo a ruptura à regra ele constrói uma interpretação guiada pela regra desrespeitada e chega a versão-matriz por uma operação de metalinguagem (...) (NASCIMENTO, 1986:336)

A versão nova da forma clichê que recebeu um tratamento pessoal, filtrado pela visão do Autor, e que permite ao leitor chegar à matriz; é como resultado do encaixe de dois segmentos: a matriz e a desconstrucão da matriz (...) além de instalar no texto surpresa mais forte e mais durável, como ressalta Lívia Ferreira Santos, provoca um jogo lúdico, no qual o leitor como participante se torna co-autor do texto. (p. 442-443):(NASCIMENTO, 1986:33)

Idênticos resultados alcançam as reelaborações coutianas; contudo, é importante ressaltar que suas reinvenções estão atreladas à postura crítica do autor, não apenas para com o senso-comum, representado pela sentença que se impõe como verdade, mas diante da própria língua herdada do colonizador, que precisa, como Mia Couto afirma na maior parte de suas entrevista, ser enriquecida pela experiência da oralidade. De língua apropriada, ela deve-se fazer língua própria do povo moçambicano. Entende-se assim a postura nada reverencial do autor, diante da norma culta padrão, e de textos cerrados (notícia de jornal, discurso político, depoimento jurídico) que frequentemente parodia satiricamente para mostrar o quanto estes possuem de artificial e ideológico; servindo tantas vezes de instrumento dominação. Em seu romance O último vôo do flamingo este recurso chega ao extremo, não só pela paródia do romance policial, gênero de literatura de massa, mas pela deformação de correspondências oficiais, discursos políticos, entre outros, para no fim revelar fatos polêmicos da atualidade e testemunhar a rede criminosa cuja dimensão é sociopolítica.

Um segundo aspecto do uso da forma paremiológica em sua obra, se dá pelo falseamento de ditos, ou melhor, a invenção de frases ao modo estrutural de um provérbio. Diferente do rebaixamento pela sátira dos ditos de origem ocidental, Mia Couto faz o oposto em grande parte de seus ditos, construindo provérbios que se amalgamam ao contexto de seus relatos e que resgatam um ensinamento mais pertinente a cosmovisão africana. O melhor exemplo disto está na obra Estórias Abensonhadas, narrativas que pontuam o fim da guerra civil em Moçambique, na qual, por meio da literatura, indica a importância do resgate de valores e pensamentos do mundo tradicional. Isto faz com que haja nesta obra, uma pletora de provérbios, alguns exemplos são: "A razão da concha é a timidez da amêijoa", "O céu do cego fica em toda parte", "Deus fez o céu para justificar os pássaros", "Sapo não sonha com charco, se alaga nele", "A morte tem sempre onde cair em nós", "Roupa do morto já não se amarrota" e "Breves são os enquantos, nenhuns os encantos". Ou seja, privilegia o homem que apreende o mundo pelo contato com a natureza; e cuja experiência cotidiana flerta diretamente com o universal (vida/morte/desígnios divinos).

Mia Couto privilegia em toda sua obra o poder expressivo do dito popular e muito largamente da máxima ("Verdade é mentira que não fala a mesma linguagem do pensamento"), cuja distinção com o primeiro, é importante ressaltar neste caso, pois está no fato de encerrar em si um sentido único, impossibilitando o encaixe (metafórico) em diferente contextos. Tal procedimento, singulariza o seu discurso, que resgata uma poeticidade em que ressoam valores tradicionais; uma sabedoria muito própria do universo africano; da qual os seus ditos recuperariam a voz (quiçá dos povos, quiçá dos ancestrais).

Já o terceiro aspecto é também o mais explícito, no qual também se faz mais evidente a adesão irrestrita ao mundo tradicional africano. Resgatado, provavelmente nas andanças que Mia Couto realiza em todo Moçambique em seu trabalho como ecologista e biólogo, os provérbios tradicionais dos diferentes grupos/etnias que povoam Moçambique são inseridos na obra, por meio do discurso direto, como epígrafe, ou mote.

O livro Mia Couto: acrediteísmos, de Fernanda Cavacas, compõe-se de uma rica seleção de ditos extraídos da obra de Mia Couto, contrapostos pela autora aos provérbios tradicionais de grupos/etnias africanas (Achirima, Bantu, Bitonga, Chope, Chuabo, Iao, Maconde, Macua, Marave, Ndau, Nianja, Sena, Tauara, Tewe, Thonga, Tsonga, Tsua) (CAVACAS, 2001:83). Embora não traga reflexões sobre o emprego, tal obra permite o reconhecimento de uma cosmovisão compartilhada entre os mais diversos grupos acerca dos ancestrais míticos, da Ancestralidade e da força da tradição, ou seja, da atuação viva dos mortos/passado, no presente, algo que o provérbio (palavra-tradição) parece materializar. Por isso, em Mia Couto, há como que uma reverência a esses ensinamentos proverbiais, pois estes 
são apresentados comumente em destaque, anunciada sua origem previamente ou, quando inseridos no texto, postos entre aspas:

Esse Iúri comprou as minas, na espera de ficar rico. Mas conforme dizem os mais velhos: não corras atrás da galinha já com o sal na mão. (...) (COUTO, 1998:74) - do Tsonga: Não corras da galinha já com o sal na mãos.

- Não esqueças; patrão. A riqueza é como o sal: só serve para temperar. (COUTO, 1992:119) - do Tsonga: A riqueza é como sal, só tempera. O principal é o amor.

Aprendamos do camaleão que de correrias nunca tropeça. (COUTO,1991:185) - do Sena: O camaleão anda devagar, há espinhos no chão.

Bem diz o provérbio: a lua morre e é grande enquanto as estrelas ainda que pequenitas, ficam a brilhar. (COUTO,1997:217) - do Macua: Em morrendo a Lua, vêem-se as estrelas.

... lembrando o ditado: onde vires o fumo, aí estão os homens; onde choram os bebés, aí estão as mulheres. (COUTO,1998:170) - do Macua: Onde estão os homens, aí está o fumo, onde estão as mulheres, aí choram os bebês.

- Preguiçoso? Eu ando é a embranquecer as palmas das mãos. (COUTO, 2004:9) - do Macua: A ociosidade não se com; faz apenas embranquecer a palma das mãos.

O macaco ficou maluco de olhar atrás do espelho", "O mundo não é o que existe, mas o que acontece", "O que não pode florir no momento certo, acaba explodindo depois"; "Queres saber onde está o gato? Pois procura no canto mais quente. (provérbios e ditos Tizangara usados como epígrafe de $O$ ultimo vôo do flamingo)

O antropólogo angolano Carlos Serrano, num ensaio sobre provérbios dos Bawoyo de Cabinda (SERRANO, 1993:137-146), escreve que "O adágio é uma das fórmulas rituais que integra os indivíduos dentro da sociedade tradicional oral, invocando a ordem estabelecida, a autoridade dos ancestrais (princípios míticos) e seus intermediários viventes: os chefes."

No contexto das sociedades africanas, o provérbio, enquanto palavra possuidora de um valor moral (saber mnemônico que preserva o saber dos ancestrais), é também um instrumento apaziguador para questões de divergência. Serrano explica que no julgamento público dos Bawoyo, ele é enunciado pelo orador e completado pela própria assistência/audiência; atualizando um saber dos ancestrais no presente chega-se a uma solução após repetidas exposições de provérbios.

Tal procedimento de Mia Couto justifica-se, portanto, no respeito e na admiração profunda que este possui para com a sabedoria tradicional, que tem na palavra o seu caráter sagrado, associada que está à "origem divina e às forças ocultas nela depositadas."

\section{Conclusão}

Em Rosa, o uso dos provérbios compreendem três etapas: transposição, apropriação da estrutura, recriação. Mia Couto realiza simultaneamente: desconstrução/ recriação dos provérbios ocidentais, invenção após apropriação da estrutura e a transposição para obra dos provérbios tradicionais. Rosa parte da transposição quase documental-etnográfica, para incorporação da forma e fragmentação do texto, tornando próprio o popular apreendido, e por fim, usando-o como recurso humorístico. Couto, numa postura combativa à língua de seus pais, que é a mesma do colonizador, estabelece uma relação de ambiguidade. Ele torna manifesta a apreensão da cultura lusitana, mas a desordena demonstrando com isto certa independência de proceder e pensar; para logo em seguida valorizar o local (moçambicano) - de olho na importância que tem o provérbio para toda cultura tradicional africana - fazendo com que, pela sentença, se manifeste o olhar do homem rústico, sua forma de entender o mundo. A reverência aos provérbios tradicionais sela, portanto, a adesão do narrador a esta perspectiva.

Walter Benjamin, que considerou o provérbio, em determinado momento, o "ideograma de uma narrativa", escreveu em seu famoso ensaio acerca da obra de Nikolai Leskov:

Ela (a verdadeira narrativa) tem sempre em si, às vezes de forma latente, uma dimensão utilitária. Essa utilidade pode consistir seja num ensinamento moral, seja numa sugestão prática, seja num provérbio ou numa norma de vida - de qualquer maneira, o narrador é um homem que sabe dar conselhos. Mas, se 'dar conselhos' parece hoje algo de antiquado, é porque as experiências estão deixando de ser comunicáveis.

\section{(...)}

Provérbios - assim seria possível dizer - são escombros, existentes no lugar de antigas estórias, nos quais a moral envolve um gesto como se fosse hera a enrolar-se em torno de muros. (BENJAMIN, 1987:217)

Guimarães Rosa e Mia Couto, que há muito se definiram como contadores de histórias, realizam em determinada medida uma aproximação entre a chamada cultura literária erudita e a popular; ambos buscam, em toda sua escrita, não só reproduzir o pensamento arcaico-popular, mas atingir um grau de estreitamento dessa relação - escritor e matéria narrada - para revelar a abrangência do ser e seu mundo retratado, capturando pela poeticidade do discurso, o próprio leitor. 
Como contadores, eles procuram, através de uma linguagem próxima do relato oral, mas permeada de dicções distintas, resgatar narrativas humanas; que, embora fincadas no real (um universo de carências extremadas) encerram mistérios. Para isto, "encenam" histórias exemplares de superação e, no caso de Mia Couto, de contundente denúncia.

Os provérbios, entrefechados nesses enredos, são sempre elementos que tornam reconhecíveis como comentário sobre a experiência humana, por vezes a sabedoria é questionada pelo viés do humor, outras, se impõe para convencimento, consolação ou aceitação resignada. Desterritorizados como os provérbios, Brasil e Moçambique, as localidades de origem, deixam de ser um espaço determinado, pois Guimarães Rosa e Mia Couto rompem com a noção de um regionalismo que faz um retrato realista das matizes locais, para fazer delas, a aldeia onde o homem e a natureza terminam por ser converter em toda parte, em toda gente: uma experiência totalizadora e universal.

\section{Referências}

ALTUNA, Raul Ruiz de Asúa. Cultura tradicional bantu. Luanda: Edição do Secretariado Arquidiocesano de Pastoral, 1985.

AFONSO, Maria Fernanda. $O$ conto moçambicano - escritas pós-coloniais. Lisboa: Editorial Caminho, 2004.

BENJAMIN, Walter. Magia e técnica, arte e politica: ensaios sobre literatura e história da cultura. São Paulo: Brasiliense, 1987.

CALOBREZI, Edna Tarabori. Morte e alteridade em "Estas estórias". São Paulo: Edusp, 2001.

CAVACAS, Fernanda. Mia Couto: pensamento e improvérbios. Lisboa: Mar Além/Instituto Camões, 2000.

CAVACAS, Fernanda. Mia Couto: acrediteísmos. Lisboa: Mar Além/Edição de Publicações/Instituto Camões, 2001.

COUTO, Mia. A varanda do frangipani. Lisboa: Editorial Caminho, 1995.

COUTO, Mia. Cada homem é uma raça (estórias). Rio de Janeiro: Nova Fronteira, 1998.

COUTO, Mia. Contos do nascer da terra. Lisboa: Editorial Caminho, 1997.

COUTO, Mia. Cronicando. Lisboa: Editorial Caminho, 1991.

COUTO, Mia. Estórias abensonhadas. Rio de Janeiro: Nova Fronteira, 1996.
COUTO, Mia. Mar me quer. Lisboa: Editorial Caminho, 2004.

COUTO, Mia. O último voo do flamingo. Lisboa: Editorial Caminho, 2000.

COUTO, Mia. Raiz de orvalho e outros poemas. Lisboa: Editorial Caminho, 1999(b).

COUTO, Mia. Terra sonâmbula. Rio de Janeiro: Nova Fronteira, 1992.

COUTO, Mia. Vinte e zinco. Lisboa: Editorial Caminho, 1999(a).

COUTO, Mia. Vozes anoitecidas. Lisboa: Editorial Caminho, 1986.

JOLLES, André. Formas simples - legenda, saga, mito, adivinha, ditado, caso, memorável, conto, chiste. São Paulo: Cultrix, 1976.

ROSA, João Guimarães. Ave palavra. Rio de Janeiro: José Olympio, 1970.

ROSA, João Guimarães. Estas estórias. Rio de Janeiro: Nova Fronteira, 1984(a).

ROSA, João Guimarães. Grande sertão: veredas. Rio de Janeiro: Nova Fronteira, 1984(b).

ROSA, João Guimarães. Manuelzão e Miguilim. Rio de Janeiro: Nova Fronteira, 1984(c).

ROSA, João Guimarães. No Urubuquaquá, no Pinhém. Rio de Janeiro: José Olympio, 1976.

ROSA, João Guimarães. Noites do sertão. Rio de Janeiro: Nova Fronteira, 1983.

ROSA, João Guimarães. Primeiras estórias. Rio de Janeiro: Nova Fronteira, 1985.

ROSA, João Guimarães. Sagarana. Rio de Janeiro: Nova Fronteira, 1971.

ROSA, João Guimarães. Tutaméia - terceiras estórias. Rio de Janeiro: Nova Fronteira, 1975.

SERRANO, Carlos. Símbolos do poder nos provérbios e nas representações gráficas Mambaya Manzangu dos Bawoyo de Cabinda-Angola. Revista do Museu de Arqueologia e Etnologia, São Paulo, v. 3, p. 137-146, 1993.

VELLASCO, Ana Maria de Moraes Sarmento. Introdução. Coletânea de provérbios e outras expressões populares brasileiras de provérbio. Disponível em: <http://www.deproverbio. com/display.php? $\mathrm{a}=4 \& \mathrm{f}=$ DPbooks \& $\mathrm{r}=$ VELLASCO/ INTRODUCAO.html>.

Recebido: 04 de março de 2015

Aprovado: 14 de abril de 2015 Contato: edduardoat@gmail.com 